Ifo Working Papers

\title{
The Structure of Europe: \\ International Input-Output Analysis with Trade in \\ Intermediate Inputs and Capital Flows
}

\author{
Sebastian Benz \\ Mario Larch \\ Markus Zimmer
}

Ifo Working Paper No. 161

May 2013

An electronic version of the paper may be downloaded from the Ifo website www.cesifo-group.de. 


\title{
The Structure of Europe: \\ International Input-Output Analysis with Trade in Intermediate Inputs and Capital Flows*
}

\begin{abstract}
In this paper we theoretically derive an international Rybczynski matrix. Its elements indicate the aggregate output change in a country when endowment with one or more factors in the same or another country is increased. This allows us to characterize the production structure in 11 countries of the European Union. Starting from a baseline case with free trade in final goods only, we analyze two types of interaction between countries: international trade of intermediate inputs and internationally mobile capital.
\end{abstract}

JEL Code: F11, F15, O30, O52.

Keywords: Rybczynski effects, input-output analysis, European Union, intermediate inputs.

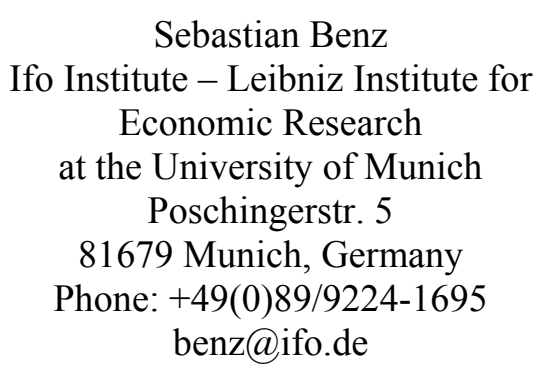

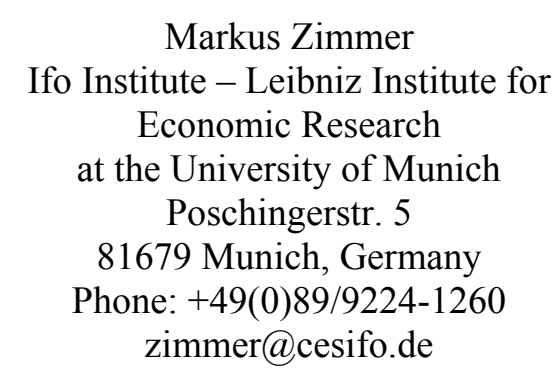

Mario Larch

University of Bayreuth,

Ifo Institute, CESifo and

GEP at University of Nottingham,

Universitätsstr. 30

95447 Bayreuth, Germany

Phone: +49(0)921/55-6240

mario.larch@uni-bayreuth.de

* We gratefully acknowledge funding from the Bavarian Ministry of Economic Affairs, Infrastructure, Transport and Technology under project "Innovationsspillovers in Deutschland". 


\section{Introduction}

Heckscher-Ohlin theory in its simplest specification (two countries, two goods, two factors) implies that the pattern of production is determined by relative factor endowments and relative factor input coefficients. Under reasonable assumptions, a higher endowment of one factor in country 1 drives up the output of the sector that relies extensively on this factor, while output of the other sector declines. If prices of final products remain constant and if the two countries are linked only via trade in final goods, the situation in Country 1 will have no impact on Country 2's output pattern.

However, there are other ways that countries are connected, one of which is capital mobility, especially in highly integrated regions such as the European Union, where barriers to capital mobility have been abolished. Moreover, in recent years there has been a growing tendency toward the international fragmentation of production. ${ }^{1}$ Not only final goods but also intermediate inputs are shipped internationally. Purely domestic flows of intermediate products are summarized in a country's input-output accounts, but there are no comparable data for international flows of intermediates. Trefler and Zhu (2010) and Johnson and Noguera (2012) make important contributions toward describing international input-output relationships, but given this new paradigm in the academic treatment of international trade, it is important to expand research in this direction.

In a recent contribution, Fisher and Marshall (2011) show how to calculate Rybczynski effects in a case where the number of sectors exceeds the number of factors empirically observed in an economy. Assuming a Leontieff production technology and constant goods prices, they argue that the Rybczynski effect can be separated into a movement that is orthogonal to the economy's linear production possibility frontier and a second movement along this frontier. The first movement can be uniquely characterized and leads to higher revenue in the economy. The second movement is arbitrary and not relevant for revenue. Hence, it is plausible to argue that the second movement is determined solely by the demand side of the economy, whereas

\footnotetext{
${ }^{1}$ See, for example, Campa and Goldberg (1997), Hummels et al. (1998, 2001), Yeats (2001), and Hanson et al. (2001, 2005).
} 
the first can be interpreted as the pure Rybczynski effect as mandated from factor supply. ${ }^{2}$

Fisher and Marshall's (2011) analysis does not consider general equilibrium effects in the form of price changes of final goods. This is because they attempt to provide a framework for calculating Rybczynski derivatives using data reported by official statistical offices, which is characterized by a high number of both sectors and production factors, the former usually exceeding the latter. Deriving production technology from sectoral employment and inputoutput data and given the assumption that one dollar of output indeed has a value of one, they calculate a vector of factor income so that prices mandated by zero profits minimize the sum of squared deviations from a unit vector. Only by coincidence will the mandated price actually be equal to one. However, if production costs are only the best linear fit for actual prices, the effect of price changes on output is everything but straightforward.

Nevertheless, the importance of general equilibrium effects for Rybczynski's (1955) theory cannot be denied. For example, in a recent extension of Rybczynski's ideas, Opp et al.(2009) demonstrate, in an analytically tractable model with two large countries, two goods, and two factors, that consumers' low willingness to substitute goods in consumption may lead to a reversion of Rybczynski's classic comparative statics in a setup in which two countries trade with each other, due to adjustments in the terms of trade. The general equilibrium effects on goods prices should be even more pronounced in a one-country analysis of the United States, a large and relatively closed economy. Hence, there is some doubt as to the validity of Fisher and Marshall's (2011) results because changes in output calculated from the production side of the economy may not be compatible with the consumption demand pattern.

With our multicountry extension we address this important shortcoming of the Fisher and Marshall (2011) framework. Our model is characterized by free trade of final consumption goods between 11 European economies. Even the GDP of Germany, the largest economy in our dataset, comprises only little more than a quarter of the total GDP of these 11 countries. This justifies the assumption of a small open economy setup, where output in one country does not

\footnotetext{
${ }^{2}$ There have already been several attempts to determine a relationship between endowments and outputs. Estimates of national revenue functions are presented by Kohli (1991) and Harrigan (1997), which attempt to explain the patterns of comparative advantage. Fitzgerald and Hallak (2004) directly estimate a Rybczynski effect in a reduced-form equation.
} 
affect prices on the common market. ${ }^{3}$ Moreover, most trade relationships are characterized by both exports and imports within narrowly defined product classes. This implies a high degree of substitutability between exports and imports in consumption, the opposite of what is required for a reversion of Rybczynski effects in Opp et al. (2009).

Thus, we are confident that our partial derivatives are a reasonable representation of regional Rybczynski effects for small endowment changes. Taking the regional level as a third dimension of analysis (in addition to goods and factors) is especially relevant in light of the current economic imbalances in Europe. Bad economic conditions in the southern economies provide incentives for migration, especially for mobile high-skilled individuals who are able to afford the fixed cost of migration. The resultant changes in regional output patterns may further aggravate the economic downturn in southern economies.

Changes in endowment of labor may be provoked not only by regional economic imbalances, but also by policy measures. Many governments consider attracting high-skilled individuals as an important national policy objective (e.g., Germany; BMBF 2010) because human capital is a major determinant of sustainable growth. ${ }^{4}$ This sort of policy includes attracting highly qualified migrants as well as activating the country's "reserves", for example, women (especially mothers) and older persons not currently participating in the labor market due to a lack of public infrastructure (e.g., childcare or vocational training) or because of labor market regulations. ${ }^{5}$ When actively engaged in, this type of policy may affect the skill structure of workers in a country, implying a change in the country's relative endowments. Migration-promoting policy measures may even affect relative endowments in two countries. The importance of the skill structure for a high GDP per capita is illustrated in Figure 1.

We use data from 11 European countries. Employment is differentiated into nine types of

\footnotetext{
${ }^{3}$ Having the baseline scenario characterized by free trade also implies that we do not have to deal with price changes due to changes in trade openness.

${ }^{4}$ This is documented by, for example, Florida (2002, 2005) and Trippl and Maier (2010).

${ }^{5}$ The literature focuses especially on the context of migration and on how employment growth as well as productivity can suffer if there is a "brain drain", which can occur when the most educated, talented, and entrepreneurial leave a region (Brezzi and Piacentini 2010; OECD 2008, 2009). While this brain drain can result purely from regional economic differences, the literature on "brain competition policy" focuses on the active attraction of high-skilled workers through national policy measures (Reiner 2010). Only recently has attention shifted to the direct impact of immigration on innovative output (Agrawal et al.2011; Hunt 2011; Hunt and Gauthier-Loiselle 2010; Marão et al.2011; Niebuhr 2010; Ozgen et al. 2011). A good overview of the issues involved in the migration of high-skilled workers can be found in Solimano (2008).
} 
Figure 1. GDP per capita and high-skilled labor force intensity

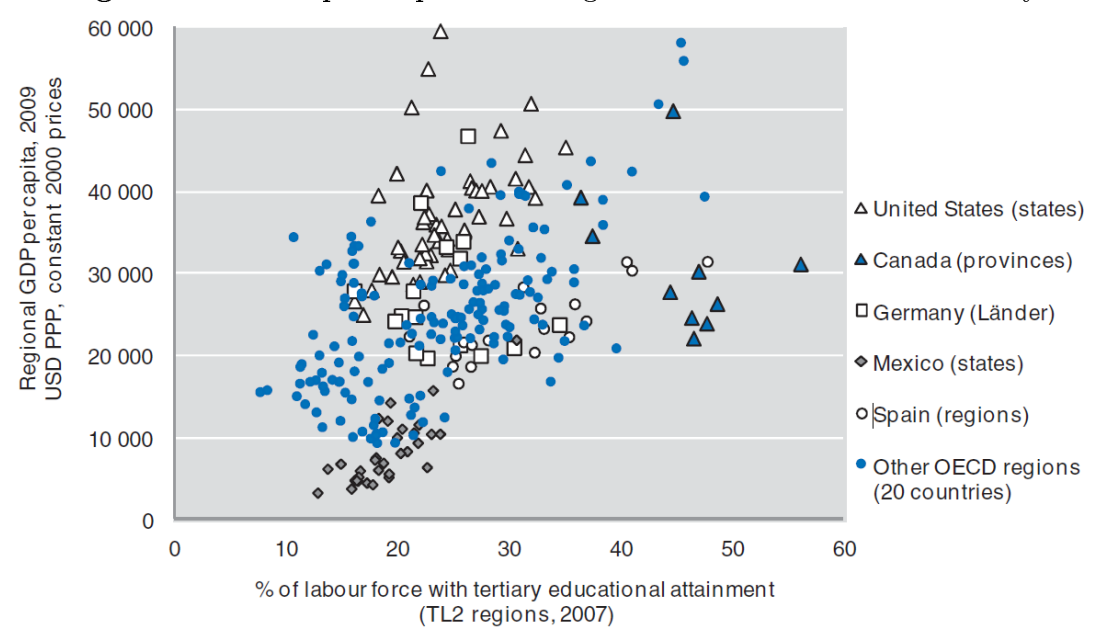

Note: The District of Columbia (United States) does not appear in the figure for ease of display as the GDP per capita is more than double the value of top OECD regions.

Source: OECD (2011): Regions and Innovation Policy

labor and the use of capital is tracked for 16 sectors in each country. Moreover, we construct $16 \times 15=240$ international bilateral input-output matrices using bilateral trade data from CEPII. This allows us to calculate a $110 \times 176$ matrix of factor-sector-country-pair-specific Rybczynski effects, which we aggregate to an $11 \times 11$ matrix of bilateral international Rybczynski effects.

When economies are integrated by trade in final products, an additional high-skilled worker is most valuable in Germany and Finland, raising annual output by roughly 33,000 Euros. When the pattern of international trade in intermediate goods is accounted for, the Rybczynski effect in Germany of an additional German high-skilled worker increases to 34,500 Euros. ${ }^{6}$ Moreover, aggregate output in all other countries is raised by roughly 5,000 Euros. Trade in intermediates does not change the output effect in Finland of a Finish high-skilled worker. However, the introduction of intermediate goods trade imposes a negative output effect of 2,500 Euros in the other countries. Additionally allowing for mobility of capital raises the positive effect of a German high-skilled worker on output in other countries to 10,500 Euros and a Finish high-skilled worker now has a positive externality of 1,500 Euros on output in other countries. In general, high-skilled workers always imply a positive externality in other

\footnotetext{
${ }^{6}$ Using a distinct framework but addressing a related question, Caliendo and Parro (2012) demonstrate in a Ricardian gravity model that the trade and welfare effects of NAFTA's tariff reductions are reduced by more than $40 \%$ when intermediate goods are not taken into account in production and input-output linkages.
} 
countries in the case with trade in intermediates and mobile capital, whereas results are mixed when capital is country specific.

The remainder of the paper is organized as follows. In section 2 we derive the international Rybczynski matrix, extending Fisher and Marshall's (2011) theory. Section 3 explains how we construct our dataset and section 4 displays the results. Section 5 concludes.

\section{Derivation of the international Rybczynski matrix}

To derive the theoretical properties of the Rybczynski matrix we use a Leontief production function with fixed input coefficients and constant returns to scale. We assume this to be a transnational production function. This means that, potentially, factor inputs from all countries are used to produce final output in one country. Output is given by

$$
y_{i k}=\min \left\{\frac{v_{i k 11}}{a_{i k 11}}, \ldots, \frac{v_{i k f l}}{a_{i k f l}}, \ldots, \frac{v_{i k F K}}{a_{i k F K}}\right\} \quad \forall i=1, \ldots, N \text { and } l=1, \ldots, K
$$

where $y_{i k}$ is output in country $k$ 's sector $i$ and $v_{i k f l}$ is the amount of country l's factor $f$ employed to produce output in country $k$ 's sector $i$ and $a_{i k f l}$ is the input coefficient that determines the efficiency of using country l's factor $f$ to produce output in country $k$ 's sector $i$. The number of countries is $K$ while the number of sectors is $N$ and the number of factors is $F$. A similar relationship holds for all countries $k$, with the input-coefficients being specific to each country. Full employment, together with the assumption that all production factors are scarce and have a strictly positive remuneration implies: ${ }^{7}$

$$
v_{k f}=\sum_{l=1}^{K} \sum_{i=1}^{N} a_{i k f l} y_{i k} \quad \forall f=1, \ldots, F \text { and } k=1, \ldots K
$$

where $y_{i k}$ is output in country $k$ 's sector $i, v_{k f}$ is the endowment with factor $f$ in country $k$ and $a_{i k f l}$ is the input coefficient. ${ }^{8}$ Since this relationship must hold for any country $k$, we have $K \times F$ such equations.

\footnotetext{
${ }^{7}$ Fisher and Marshall (2011) show that the analysis neither requires scarcity of all production factors nor positive output in all sectors.

${ }^{8}$ For a more flexible production technology, it is the average input coefficient that is optimal to produce each $y_{i} k$ given output prices and factor prices.
} 
In matrix notation for all $K$ times $F$ country-specific production factors this relationship can be written as:

$$
\boldsymbol{v}=\boldsymbol{A}^{\prime} \boldsymbol{y}
$$

where $\boldsymbol{v}$ is the endowment vector of length $K F$, containing information about the factor endowment in all countries, defined as:

$$
\boldsymbol{v}=\left[\begin{array}{c}
v_{1} \\
\vdots \\
v_{K}
\end{array}\right]
$$

where each $v_{k}$ is a vector of length $F$. Furthermore, the vector of final output $\boldsymbol{y}$ is of length $K N$ and defined as:

$$
\boldsymbol{y}=\left[\begin{array}{c}
y_{1} \\
\vdots \\
y_{K}
\end{array}\right]
$$

where each $y_{k}$ is a vector of length $N$ and the matrix of direct and indirect factor inputs $\boldsymbol{A}$ is of dimension $K N \times K F$ and defined as:

$$
\boldsymbol{A}=\left[\begin{array}{ccc}
A_{11} & \cdots & A_{1 K} \\
\vdots & \ddots & \vdots \\
A_{K 1} & \cdots & A_{K K}
\end{array}\right]
$$

where each $A_{k k}$ on the main diagonal characterizes factor input coefficients for domestic factors in domestic production and each $A_{k l}$ off the main diagonal characterizes factor input coefficients for foreign factor inputs in domestic production. Each $A$-matrix is a matrix of direct and indirect factor inputs. Intuitively, this matrix describes the infinite sum of all rounds of intermediate inputs into production. Hence, every element of the matrix is potentially different from zero. How can the coefficients of this matrix be determined? We first have to define a matrix of direct factor inputs $\boldsymbol{B}$. In our baseline specification, all factors are immobile between countries. This implies that direct factor inputs can come only from the 
country where the final output is produced. The coefficients of $\boldsymbol{B}$ are given by the relationship

$$
v_{k f}=\sum_{i=1}^{N} b_{i k f} x_{i k} \quad \forall f=1, \ldots, F \text { and } k=1, \ldots K,
$$

where $x_{i k}$ is the overall production level, including the production of intermediate inputs that will not be used to satisfy final demand. Since this relationship must hold for any country $k$ and any factor $f$, we have $F$ times $K$ such equations.

In matrix notation this can be written as:

$$
\boldsymbol{v}=\boldsymbol{B}^{\prime} \boldsymbol{x}
$$

where, as above, $\boldsymbol{v}$ is the endowment vector of length $F K$, containing information about the factor endowment in all countries. Furthermore,

$$
\boldsymbol{x}=\left[\begin{array}{c}
x_{1} \\
\vdots \\
x_{K}
\end{array}\right]
$$

is the vector of overall production including intermediate products of length $N K$ and

$$
\boldsymbol{B}=\left[\begin{array}{ccc}
B_{11} & \cdots & 0 \\
\vdots & \ddots & \vdots \\
0 & \cdots & B_{K K}
\end{array}\right]
$$

is the $N K \times F K$ matrix of direct factor inputs. In our baseline specification, where all production factors are immobile internationally, only the matrices on the main diagonal of $\boldsymbol{B}$ contain positive input coefficients. All the matrices off the main diagonal are zero because no foreign factors are directly used to produce domestic output.

From equation (3) and equation (8) we obtain:

$$
\boldsymbol{A}^{\prime} y=\boldsymbol{B}^{\prime} x
$$


Matrix $\boldsymbol{B}^{\prime}$ can be easily constructed from publicly available data sources. However, as mentioned above, it is matrix $\boldsymbol{A}^{\prime}$ in which we are interested. Their relationship can be conveniently derived from a system of linear equations. In every sector $i$ and every country $k$ the following accounting identity must hold:

$$
\sum_{l=1}^{K} \sum_{j=1}^{N} x_{i k j l}+y_{i k}=x_{i k} \quad \forall i=1, \ldots, N \text { and } k=1, \ldots K
$$

where $x_{i k j l}$ are intermediate goods from country $l$ 's sector $i$ used for production in country $k$ 's sector $j, y_{i k}$ is output of final consumption goods and $x_{i k}$ is overall production in country $k$ 's sector $i$. When input coefficients are constant, intermediate inputs depend linearly on final demand. This relationship can be written as:

$$
x_{i k j l}=z_{i k j l} x_{j l}
$$

where the canonical element $z_{i k j l}$ is the amount of good $\mathrm{i}$ that is needed as intermediate

$$
\sum_{l=1}^{K} \sum_{j=1}^{N} z_{i k j l} x_{j l}+y_{i k}=x_{i} \quad \forall i=1, \ldots, N \text { and } k=1, \ldots K
$$

which in matrix notation is:

$$
Z x+y=x,
$$

where the matrix of average intermediate inputs coefficients $\boldsymbol{Z}$ is a $N K \times N K$ matrix defined as:

$$
\boldsymbol{Z}=\left[\begin{array}{ccc}
Z_{11} & \cdots & Z_{1 K} \\
\vdots & \ddots & \vdots \\
Z_{K 1} & \cdots & Z_{K K}
\end{array}\right]
$$

with each submatrix being of dimension $N \times N$. The matrices on the main diagonal $Z_{k k}$ are, of course, the input-output matrices from the statistical offices, while the matrices off the main diagonal are international input-output matrices. The coefficients of these matrices are fixed Leontief input coefficients but can also be interpreted as those that are optimal for given factor prices and currently prevailing goods prices. The solution to this system of equations 
is:

$$
\boldsymbol{x}=(\boldsymbol{I}-\boldsymbol{Z})^{-1} \boldsymbol{y}=\boldsymbol{C y}
$$

where $\boldsymbol{I}$ is the identity matrix of size $N K \times N K$. The matrix $\boldsymbol{C}=(\boldsymbol{I}-\boldsymbol{Z})^{-1}$ is then called the matrix of inverse Leontief coefficients. This matrix indicates the overall production level necessary to satisfy a unit vector of final demand, given the infinite rounds of intermediate production. Inserting Equation (17) into Equation (11) we obtain:

$$
\boldsymbol{A}^{\prime}=\boldsymbol{B}^{\prime} \boldsymbol{C}=\boldsymbol{B}^{\prime}(\boldsymbol{I}-\boldsymbol{Z})^{-1}
$$

As already mentioned, in the case of mobile production factors we have data on more goods than factors, $N>F$. This means that full employment can be determined as defined above. However, it implies that the empirical production possibility frontier is linear. Many possible output combinations lead to the same demand for production factors. Or, stated differently, $F$ times $K$ full employment conditions do not determine $N$ times $K$ zero-profit conditions. It is not possible to solve Equation (11) for the vector $\boldsymbol{y}$ because matrix $\boldsymbol{A}^{\prime}$ is not invertible.

Following Fisher \& Marshall (2010), this problem is avoided by using the Moore-Penrose pseudoinverse. ${ }^{9}$ Using this pseudoinverse of $\boldsymbol{A}^{\prime}$ denoted by $\left(\boldsymbol{A}^{\prime}\right)^{+}$it is possible to write:

$$
\boldsymbol{y}=\left(\boldsymbol{A}^{\prime}\right)^{+} \boldsymbol{v}+\left(\boldsymbol{I}-\left(\boldsymbol{A}^{\prime}\right)^{+}\left(\boldsymbol{A}^{\prime}\right)\right) \boldsymbol{z}
$$

where $\boldsymbol{z}$ is an arbitrary $N K \times 1$ vector. However, the arbitrary part of $\boldsymbol{y}$ is not relevant for the value of output as given by the revenue function $\boldsymbol{Y}=\boldsymbol{p}^{\prime} \boldsymbol{y}$. This can be shown since when all $N$ zero-profit conditions hold with equality, the price vector $\boldsymbol{p}$ must lie in the column space of $\boldsymbol{A}$, because each good's price in each country is a weighted sum of $F$ times $K$ factor prices. This implies that $\boldsymbol{p}^{\prime}\left(\boldsymbol{I}-\left(\boldsymbol{A}^{\prime}\right)^{+}\left(\boldsymbol{A}^{\prime}\right)\right) \boldsymbol{z}=0$ for any $\boldsymbol{z}$. Therefore, $\boldsymbol{y}=\left(\boldsymbol{A}^{\prime}\right)^{+} \boldsymbol{v}$ is sufficient as a solution for the output as determined by the supply side of the economy, whereas all other changes in sectoral output are demand driven. This allows defining a $F K \times N K$ Rybczynski

\footnotetext{
${ }^{9}$ This matrix is described by Moore (1920), Bjerhammar (1951), and Penrose (1955). See Albert (1972) for a nice exposition of its properties.
} 
matrix that indicates marginal output responses to marginal changes in factor supply as:

$$
\frac{\mathrm{d} \boldsymbol{y}}{\mathrm{d} \boldsymbol{v}}=\left(\boldsymbol{A}^{\prime}\right)^{+}
$$

where the element whose row is indexed by $f k$ and column by $i l$ indicates the output effect in country l's sector $i$ caused by a marginal increase in the supply with country $k$ 's factor $f$.

To calculate the aggregate Rybczynski effect of country $k$ 's factor $f$ on output in country $l$, we simply sum over the $N$ columns in a row $f k$ that belong to country $l$ :

$$
R_{f k l}=\sum_{i \in \mathcal{L}} \frac{\mathrm{d} y_{i l}}{\mathrm{~d} v_{f k}}
$$

where $\mathcal{L}$ characterizes the set of sectors that belong to country $l$. To calculate the aggregate Rybczynski effect of all factors in country $k$ on output in country $l$ we further take the sum over all factors $f$ in country $k$, which can be written as:

$$
R_{k l}=\sum_{f \in \mathcal{K}} R_{f k l}=\sum_{f \in \mathcal{K}} \sum_{i \in \mathcal{L}} \frac{\mathrm{d} y_{i l}}{\mathrm{~d} v_{f k}},
$$

where $\mathcal{K}$ characterizes the set of factors that belong to country $k$. In Section 4.1 we report the aggregate bilateral Rybczynski effects $R_{k l}$. However, for the sake of comparison between different specifications of capital mobility in our model, we specify the set of factors $\mathcal{K}$ to comprise labor in country $k$, but not capital from country $k$. In Section 4.2 we report Rybczynski effects $R_{f k l}$ for the factor $f$ of high-skilled workers in each country.

\section{Database and international input-output matrices}

The most important data sources for our analysis are the EU member countries' input-output tables from Eurostat. We use input-output data from 2005 in basic prices, which comprise 59 sectors. We aggregate these data to obtain smaller matrices with 16 sectors. This allows us to merge the input-output data with data on sectoral employment in nine employment categories from Eurostat and sectoral capital from EU Klems (see Mahony and Timmer 
2009). Compared to other sources of internationally harmonized input-output data, such as the OECD Structural Analysis Database (STAN) or the World Input-Output Database (WIOD), the main advantage of using Eurostat data is the availability of information on heterogeneous labor and capital stocks in each sector, which is required for our analysis.

\begin{tabular}{|c|c|c|}
\hline $\mathrm{N}$. & Sector & Comprises \\
\hline 1 & Agriculture, forestry and fishing & $\begin{array}{l}\text { Products of agriculture, hunting and related services; Products of } \\
\text { forestry, logging and related services; Fish and other fishing products; } \\
\text { Services incidental of fishing }\end{array}$ \\
\hline 2 & Mining and quarrying & $\begin{array}{l}\text { Coal and lignite; Peat; Crude petroleum and natural gas; Services } \\
\text { incidental to oil and gas extraction excluding surveying; Uranium and } \\
\text { thorium ores; Metal ores; Other mining and quarrying products }\end{array}$ \\
\hline 3 & Manufacturing & $\begin{array}{l}\text { Food products and beverages; Tobacco products; Textiles; Wearing } \\
\text { apparel; Furs; Leather and leather products; Wood and products of } \\
\text { wood and cork (except furniture); Articles of straw and plaiting ma- } \\
\text { terials; Pulp, paper and paper products; Printed matter and recorded } \\
\text { media; Coke, refined petroleum products and nuclear fuels; Chemicals, } \\
\text { chemical products and man-made fibers; Rubber and plastic products; } \\
\text { Other non-metallic mineral products; Basic metals; Fabricated metal } \\
\text { products, except machinery and equipment; Machinery and equip- } \\
\text { ment n.e.c.; Office machinery and computers; Electrical machinery } \\
\text { and apparatus n.e.c.; Radio, television and communication equipment } \\
\text { and apparatus; Medical, precision and optical instruments, watches } \\
\text { and clocks; Motor vehicles, trailers and semi-trailers; Other transport } \\
\text { equipment; Furniture; Other manufactured goods n.e.c.; Secondary } \\
\text { raw materials }\end{array}$ \\
\hline 4 & Electricity, gas and water Supply & $\begin{array}{l}\text { Electrical energy, gas, steam and hot water; Collected and purified } \\
\text { water; Distribution services of water }\end{array}$ \\
\hline 5 & Construction & Construction work \\
\hline 6 & $\begin{array}{l}\text { Wholesale and retail trade; Repair } \\
\text { of motor vehicles and motorcycles }\end{array}$ & $\begin{array}{l}\text { Trade, maintenance and repair services of motor vehicles and motor- } \\
\text { cycles; Retail sale of automotive fuel; Wholesale trade and commission } \\
\text { trade services, except of motor vehicles and motorcycles; Retail trade } \\
\text { services, except of motor vehicles and motorcycles; Repair services of } \\
\text { personal and household goods }\end{array}$ \\
\hline 7 & Transportation and storage & $\begin{array}{l}\text { Land transport; Transport via pipeline services; Water transport ser- } \\
\text { vices; Air transport services; Supporting and auxiliary transport ser- } \\
\text { vices; Travel agency services }\end{array}$ \\
\hline 8 & $\begin{array}{l}\text { Accommodation and food service } \\
\text { activities }\end{array}$ & Hotel and restaurant services \\
\hline 9 & Information and communication & Post and telecommunication services \\
\hline 10 & Financial and insurance activities & $\begin{array}{l}\text { Financial intermediation services, except insurance and pension fund- } \\
\text { ing services; Insurance and pension funding services, except compul- } \\
\text { sory social security services; Services auxiliary to financial intermedi- } \\
\text { ation }\end{array}$ \\
\hline 11 & Real estate activities & Real estate services \\
\hline 12 & $\begin{array}{l}\text { Renting of machinery and equip- } \\
\text { ment and other business activities }\end{array}$ & $\begin{array}{l}\text { Renting services of machinery and equipment without operator and } \\
\text { of personal and household goods; Computer and related services; Re- } \\
\text { search and development services; Other business services }\end{array}$ \\
\hline 13 & $\begin{array}{l}\text { Public administration and defense; } \\
\text { compulsory social security }\end{array}$ & $\begin{array}{l}\text { Public administration and defense services; Compulsory social secu- } \\
\text { rity services }\end{array}$ \\
\hline 14 & Education & Education services \\
\hline 15 & $\begin{array}{l}\text { Human health and social work ac- } \\
\text { tivities }\end{array}$ & $\begin{array}{l}\text { Health and social work services; Sewage and refuse disposal services; } \\
\text { Sanitation and similar services }\end{array}$ \\
\hline 16 & $\begin{array}{l}\text { Other community, social, and per- } \\
\text { sonal services }\end{array}$ & $\begin{array}{l}\text { Membership organization services n.e.c.; Recreational, cultural and } \\
\text { sporting services; Other services; Private households with employed } \\
\text { persons }\end{array}$ \\
\hline
\end{tabular}

Table 1. List of sectors.

Ideally, we would also like to have international input-output tables. In other words, we would like to know the volume of bilateral trade flows from the industry where the product 
originates to the industry in which the product is used. Since these data are not available, we use a proportionality assumption to calculate the international input-output table as proposed by the OECD: ${ }^{10}$

"This technique assumes that an industry uses an import of a particular product in proportion to its total use of that product. For example if an industry such as motor vehicles uses steel in its production processes and 10 per cent of all steel is imported, it is assumed that 10 per cent of the steel used by the motor vehicle industry is imported." (OECD, 2002)

Technically, we calculate the international input-output matrix as:

$$
Z_{k l}=m_{k l} Z_{l} q_{l}^{-1}
$$

where $\boldsymbol{Z}_{\boldsymbol{k} \boldsymbol{l}}$ is the international input-output matrix that indicates in its row $i$ and column $j$ flows from country $k$ 's sector $i$ to country l's sector $j, \boldsymbol{m}_{\boldsymbol{k l}}$ is a $N \times 1$ vector calculated as imports from country $l, Z_{\boldsymbol{l}}$ is the $N \times N$ input-output matrix of country $l$, and $\boldsymbol{q}_{\boldsymbol{l}}$ is the $1 \times N$ vector of usage of products from all industries in country $l$.

Bilateral trade data are from the CEPII Baci database. We use a correspondence table from EU RAMON ${ }^{11}$ to obtain bilateral trade flows for the 16 sectors described above.

\section{Results}

Following Fisher and Marshall (2011), we compute a full matrix of Rybczynski effects. As explained in Section 2, this Rybczynski matrix captures differential effects at the sectorfactor-country level for 11 countries, 16 sectors, and 10 factors, including nine types of labor plus capital. To highlight the importance of spillovers between countries, we aggregate the individual effects at the country level, resulting in an $11 \times 11$ matrix of output effects. As an

\footnotetext{
${ }^{10}$ The same or a slightly modified assumption is used by Feenstra and Hanson (1996, 1999), Hummels et al. (2001), and Yi (2003), among others.

${ }^{11}$ http: //ec .europa.eu/eurostat/ramon/
} 
indicator of the aggregate international Rybczynski effect we report the sum of effects on all other countries in the last column of each table (indicated by a $\Sigma$ ). In the last row of each table, we report the sum of effects from all other countries, also indicated by a $\Sigma$. Note that our choice of $\Sigma$ is also intended to indicate that each element of this column (row) is simply the row (column) sum excluding the element on the main diagonal.

As we are specifically interested in the interdependencies between countries, we present three different scenarios. Our baseline specification assumes free trade in final goods only. In our first extension, we assume a production technology that requires intermediate inputs from abroad in concordance with the international input-output data. This provides an international link, such that changes in factor endowments in one country lead not only to reallocations of factors in this country, but in all countries connected. In a further extension, we relax the assumption of internationally immobile capital and instead consider perfectly mobile capital, not only between sectors of the same economy, but also across countries.

In each of these scenarios we first calculate economy-wide aggregate Rybczynski effects. These Rybczynski effects indicate the additional value of output if an economy is endowed with an additional worker of each type. The economy that experiences the increase in labor endowment is indicated by the row of the table; the resulting output effect in each country is indicated in each column. Output values are in Euros. Thereafter, we calculate Rybczynski effects of an additional high-skilled worker.

\subsection{Economy-wide Rybczynski effects}

\subsubsection{Benchmark case: trade in final goods}

In the benchmark case we assume that trade in final goods is free but that on the production side there is no interaction between countries. All factors are immobile internationally and intermediate inputs are sourced only domestically. In technical terms, matrix $\boldsymbol{Z}$ contains only the national input-output matrices $Z_{k k}$ on the diagonal, while all sub-matrices off the diagonal consist of zeros. This implies that endowment changes in an economy do not have

repercussions on the output of other economies, neither as to the aggregate value of output, 
nor as to sectoral distribution.

As highlighted in Table 2 the own-country effects vary substantially across the 11 countries. The biggest output effect, 712,713 Euros, is found for Denmark and the smallest, 223,005 Euros, for the United Kingdom. Since these numbers indicate the aggregate value of all nine types of labor in the respective economy, they must also correspond to the sum of annual salaries.

\begin{tabular}{l|ccccccccccc}
\hline & AT & CZ & DK & ES & FI & GE & IT & NL & SL & SW & UK \\
\hline AT & 616,526 & 0 & 0 & 0 & 0 & 0 & 0 & 0 & 0 & 0 & 0 \\
CZ & 0 & 283,215 & 0 & 0 & 0 & 0 & 0 & 0 & 0 & 0 & 0 \\
DK & 0 & 0 & 712,713 & 0 & 0 & 0 & 0 & 0 & 0 & 0 & 0 \\
ES & 0 & 0 & 0 & 393,156 & 0 & 0 & 0 & 0 & 0 & 0 & 0 \\
FI & 0 & 0 & 0 & 0 & 563,154 & 0 & 0 & 0 & 0 & 0 & 0 \\
GE & 0 & 0 & 0 & 0 & 0 & 390,062 & 0 & 0 & 0 & 0 & 0 \\
IT & 0 & 0 & 0 & 0 & 0 & 0 & 453,329 & 0 & 0 & 0 & 0 \\
NL & 0 & 0 & 0 & 0 & 0 & 0 & 0 & 702,672 & 0 & 0 & 0 \\
SL & 0 & 0 & 0 & 0 & 0 & 0 & 0 & 0 & 294,403 & 0 & 0 \\
SW & 0 & 0 & 0 & 0 & 0 & 0 & 0 & 0 & 0 & 461,120 & 0 \\
UK & 0 & 0 & 0 & 0 & 0 & 0 & 0 & 0 & 0 & 0 & 223,005 \\
\hline
\end{tabular}

Table 2. Economy-wide Rybczynski effects of an additional worker of each type.

\subsubsection{Extension 1: trade in intermediate inputs}

In this section, we perform the same exercise with a full matrix $\boldsymbol{Z}$, including national and international input-output data. The international input-output matrices are calculated as described in Section 3. This implies that producers in all other countries have to adjust their production patterns so as to deliver the intermediate inputs required for production in the country where endowment is increased. Intuitively, for countries that deliver many intermediate products to the respective country, this constraint may prevent them from maintaining the production pattern that maximizes output in the absence of trade in intermediates. However, countries that source a large share of intermediate products from the respective country may even experience an increase in output.

The own-country effects on the main diagonal of Table 3 are usually just marginally smaller than the effects in Table 2. An outlier is Germany, which experiences a decline from 390, 062 to 377,245 Euros. Also interesting is that the Czech Republic and Slovenia are the two countries that now have a larger Rybczynski effect on own output than was the case in 
the free trade in final goods only scenario.

Not surprisingly, the effects on other countries differ substantially across countries. These differences are already striking if we look only at the aggregate strength of the effect indicated in the last column of Table 3, which is simply the sum of effects on all countries other than itself. Clearly, a higher labor endowment in Germany is the situation that is most harmful to the other countries. Aggregate output of all other countries declines even more than it rises in Germany. On the other hand, Slovenia has the smallest negative impact on the other countries, even allowing three of the remaining 10 countries to increase their output, namely, Spain, Finland, and Sweden.

In the last row of Table 3 we report the aggregate impact experienced by a country, which must be understood as the output effect in one country if all other countries undergo an increase in labor endowment. Hence, by construction it is equal to the sum over all rows of a column, excluding the element on the main diagonal. This effect is largest for Austria and Sweden, mostly driven by a very strong negative effect when endowment in Germany is increased. The country least affected by such a European-wide change is Spain, indicating that Spain is not an important producer of intermediate inputs.

The regional distribution of effects is also very heterogeneous. Endowment increases in Denmark and Spain have a very similar aggregate impact on all other countries. However, whereas in the case of Denmark, it is Sweden that suffers most, accounting for more than half the aggregate effect, a higher labor endowment in Spain affects many countries very similarly, with the United Kingdom and Germany being the two that suffer most.

\subsubsection{Extension 2: mobile capital}

In Table 4 we report results for the same exercise, but with a further channel of international interaction. We now assume capital to be internationally mobile. This means that instead of $11 \times 10=110$ production factors, we now have only $11 \times 9+1=100$, that is, nine types of labor in each country plus mobile capital. Interestingly, output effects in some countries change substantially with the introduction of this additional channel, whereas output changes 


\begin{tabular}{l|ccccccccccc|c}
\hline & AT & CZ & DK & ES & FI & GE & IT & NL & SL & SW & UK & $\Sigma$ \\
\hline AT & 613,193 & $-1,390$ & $-3,745$ & $-1,093$ & $-2,304$ & 452 & -215 & -906 & $-14,496$ & $-1,498$ & $-2,906$ & $-28,100$ \\
CZ & $-8,338$ & 283,782 & $-1,995$ & -733 & $-1,247$ & $-17,205$ & $-2,115$ & $-5,475$ & $-2,215$ & $-3,317$ & $-3,064$ & $-45,705$ \\
DK & $-2,028$ & $-1,739$ & 712,561 & $-1,110$ & $-7,635$ & $-6,031$ & $-1,563$ & $-5,627$ & $-1,270$ & $-38,241$ & $-5,069$ & $-70,314$ \\
ES & $-6,995$ & $-2,465$ & $-5,442$ & 393,075 & $-3,544$ & $-12,760$ & $-4,399$ & $-4,168$ & $-6,908$ & $-6,358$ & $-13,611$ & $-66,649$ \\
FI & $-2,486$ & $-1,151$ & $-6,678$ & -666 & 562,554 & $-1,497$ & 63 & $-1,432$ & $-1,591$ & $-6,509$ & $-1,236$ & $-23,183$ \\
GE & $-110,339$ & $-38,692$ & $-50,316$ & $-16,364$ & $-26,831$ & 377,245 & $-30,017$ & $-61,961$ & $-21,812$ & $-78,683$ & $-46,834$ & $-481,850$ \\
IT & $-31,776$ & $-6,844$ & $-15,335$ & $-12,022$ & $-12,147$ & $-32,977$ & 448,180 & $-4,758$ & $-38,848$ & $-22,854$ & $-13,269$ & $-190,830$ \\
NL & $-10,032$ & $-4,730$ & $-13,625$ & $-3,546$ & $-10,799$ & $-14,181$ & $-4,822$ & 701,280 & $-6,064$ & $-10,444$ & $-14,878$ & $-93,122$ \\
SL & $-3,338$ & $-1,060$ & -325 & 93 & 42 & $-4,227$ & $-10,504$ & $-2,691$ & 295,539 & 637 & -672 & $-22,046$ \\
SW & $-4,931$ & $-2,689$ & $-48,981$ & $-1,830$ & $-31,965$ & $-11,687$ & $-3,247$ & $-10,308$ & $-1,533$ & 455,206 & $-8,917$ & $-126,088$ \\
UK & $-6,126$ & -591 & $-17,059$ & $-6,197$ & $-7,888$ & $-23,892$ & $-6,644$ & 10,770 & $-1,497$ & $-29,286$ & 222,592 & $-88,412$ \\
\hline$\Sigma$ & $-186,390$ & $-61,351$ & $-163,502$ & $-43,469$ & $-104,318$ & $-124,005$ & $-63,462$ & $-86,558$ & $-96,235$ & $-196,555$ & $-110,457$ & \\
\hline
\end{tabular}

Table 3. Economy-wide Rybczynski effects of an additional worker of each type with intermediate input trade.

in other countries seem to be driven by capital movements to a much smaller extent than they are by trade in intermediate inputs.

Looking first at the main diagonal, the biggest change compared to Table 3 occurs for Sweden, which seems to benefit from huge capital inflows as a response to a higher endowment with labor. Other elements on the main diagonal that change substantially are those for Finland and Slovenia. An interesting case is the Netherlands. This country experiences less of an increase in output when it has a higher labor endowment and mobile capital than it does in the case of immobile capital. This finding indicates that returns to capital in the Netherlands are so low that the liberation of capital flows leads to an outflow of capital, even when labor endowment rises.

In the last column of Table 4, where the aggregate effect on other countries is reported, we find large changes, compared to Table 3, for the Czech Republic and Denmark. A higher labor endowment in these countries seems to attract a great deal of capital from other countries, making these countries smaller in terms of output. Interestingly, these large capital flows do not result in much output change in the Czech Republic and Denmark themselves, compared to the case where capital is immobile, indicating that capital is used relatively less efficiently in these two countries. Both countries attract a high amount of capital from Sweden, and Denmark also attracts a great deal of capital from the Czech Republic.

Logically, Sweden and the Czech Republic are also the countries that suffer most from aggregate increases in the labor endowment of all other countries, not only in comparison with 


\begin{tabular}{l|ccccccccccc|c}
\hline & AT & CZ & DK & ES & FI & GE & IT & NL & SL & SW & UK & $\Sigma$ \\
\hline AT & 713,769 & $-11,688$ & $-4,391$ & $-1,318$ & $-3,013$ & 1,118 & -646 & -759 & $-18,445$ & $-8,528$ & $-3,185$ & $-50,855$ \\
CZ & $-12,085$ & 308,794 & $-5,773$ & $-1,962$ & $-3,498$ & $-19,060$ & $-5,919$ & $-4,700$ & $-3,796$ & $-51,113$ & $-3,632$ & $-111,539$ \\
DK & $-3,604$ & $-62,359$ & 729,318 & $-1,912$ & $-9,467$ & $-8,714$ & $-4,984$ & $-6,056$ & $-1,566$ & $-81,273$ & $-5,733$ & $-185,667$ \\
ES & $-7,660$ & $-11,586$ & $-5,643$ & 449,717 & $-4,305$ & $-13,049$ & $-6,497$ & $-3,993$ & $-9,745$ & $-14,266$ & $-13,700$ & $-90,444$ \\
FI & $-3,546$ & $-9,619$ & $-7,210$ & -881 & 703,412 & -19 & 884 & 168 & $-2,575$ & $-20,230$ & -507 & $-43,535$ \\
GE & $-115,656$ & $-51,935$ & $-49,797$ & $-16,871$ & $-31,018$ & 435,671 & $-35,294$ & $-60,592$ & $-30,509$ & $-101,388$ & $-47,228$ & $-540,286$ \\
IT & $-32,400$ & $-8,663$ & $-14,673$ & $-12,119$ & $-13,730$ & $-33,736$ & 535,994 & $-4,758$ & $-51,322$ & $-29,899$ & $-13,375$ & $-214,675$ \\
NL & $-10,782$ & $-15,003$ & $-13,166$ & $-3,500$ & $-11,659$ & $-10,712$ & $-4,526$ & 683,659 & $-7,147$ & $-20,842$ & $-13,389$ & $-110,727$ \\
SL & $-4,061$ & $-6,673$ & $-1,922$ & -38 & -998 & 2,263 & 6,375 & $-1,244$ & 388,613 & $-2,344$ & -309 & $-8,951$ \\
SW & $-7,110$ & $-26,632$ & $-55,151$ & $-2,550$ & $-43,414$ & $-12,733$ & $-4,795$ & $-10,441$ & $-2,861$ & 796,891 & $-9,217$ & $-174,904$ \\
UK & $-6,611$ & $-6,390$ & $-17,097$ & $-6,195$ & $-9,125$ & $-23,049$ & $-6,964$ & 11,460 & $-2,694$ & $-40,808$ & 253,292 & $-107,472$ \\
\hline$\Sigma$ & $-203,514$ & $-210,549$ & $-174,823$ & $-47,345$ & $-130,226$ & $-117,692$ & $-62,365$ & $-80,914$ & $-130,662$ & $-370,690$ & $-110,274$ & \\
\hline
\end{tabular}

Table 4. Economy-wide Rybczynski effects of an additional worker of each type with intermediate input trade and mobile capital.

Table 3 but also in absolute terms. Both countries experience a huge negative Rybczynski effect from endowment changes, and the effect is similar to that observed in the case of immobile capital. Rybczynski effects originating from the Czech Republic and Denmark have the largest impact on Sweden, while Rybczynski effects originating from Denmark and Sweden have the largest effect on the Czech Republic. The difference between the results in Tables 3 and 4 implies large capital flows between these countries.

\subsection{Professionals}

What is the effect of high-skilled workers on production in countries integrated by intermediate goods trade and/or mobile capital? From a public policy perspective, this question is of special interest. Countries invest in their public education systems to increase the share of high-skilled workers in the population and immigration legislation in many countries is biased toward the high-skilled. Within Europe, where there are no barriers to international migration, highskilled people are generally more mobile than the low-skilled. With our analysis, we can provide a detailed answer to the question of what a change in the number of high-skilled workers in one or more European countries implies for output in each other country.

The labor category in our data that is most likely to include high-skilled workers is that of "Professionals" as classified by the ISCO-88 system. "Professionals increase the existing stock of knowledge, apply scientific or artistic concepts and theories, teach about the foregoing in a systematic manner, or engage in any combination of these three activities. Most occupations 
in this major group require skills at the fourth ISCO skill level."12 Thus, in the following we report Rybczynski effects for "Professionals" for the same three specifications of international interaction as in Section 4.1.

\subsubsection{Benchmark case: trade in final goods}

We again begin with our benchmark scenario: free trade in final goods. Contrary to our findings above, we now see negative figures on the main diagonal for some countries. These negative Rybczynski effects seem counterintuitive at first glance. However, the logic of the Rybczynski theorem implies that every additional "Professional" must draw off resources from other sectors. The negative effect in some sectors may dominate the positive effect in other sectors, yielding an aggregate negative coefficient. ${ }^{13}$

\begin{tabular}{|c|c|c|c|c|c|c|c|c|c|c|c|}
\hline & $\mathrm{AT}$ & $\mathrm{CZ}$ & $\mathrm{DK}$ & $\mathrm{ES}$ & $\mathrm{FI}$ & $\mathrm{GE}$ & $\mathrm{IT}$ & $\mathrm{NL}$ & $\mathrm{SL}$ & SW & UK \\
\hline $\mathrm{AT}$ & 12,819 & 0 & 0 & 0 & 0 & 0 & 0 & 0 & 0 & 0 & 0 \\
\hline $\mathrm{CZ}$ & 0 & $-10,588$ & 0 & 0 & 0 & 0 & 0 & 0 & 0 & 0 & 0 \\
\hline DK & 0 & 0 & $-23,470$ & 0 & 0 & 0 & 0 & 0 & 0 & 0 & 0 \\
\hline $\mathrm{ES}$ & 0 & 0 & 0 & 27,169 & 0 & 0 & 0 & 0 & 0 & 0 & 0 \\
\hline FI & 0 & 0 & 0 & 0 & 32,864 & 0 & 0 & 0 & 0 & 0 & 0 \\
\hline $\mathrm{GE}$ & 0 & 0 & 0 & 0 & 0 & 32,990 & 0 & 0 & 0 & 0 & 0 \\
\hline IT & 0 & 0 & 0 & 0 & 0 & 0 & $-79,687$ & 0 & 0 & 0 & 0 \\
\hline NL & 0 & 0 & 0 & 0 & 0 & 0 & 0 & 7,779 & 0 & 0 & 0 \\
\hline $\mathrm{SL}$ & 0 & 0 & 0 & 0 & 0 & 0 & 0 & 0 & 4,406 & 0 & 0 \\
\hline SW & 0 & 0 & 0 & 0 & 0 & 0 & 0 & 0 & 0 & $-79,788$ & 0 \\
\hline UK & 0 & 0 & 0 & 0 & 0 & 0 & 0 & 0 & 0 & 0 & 21,196 \\
\hline
\end{tabular}

Table 5. Economy-wide Rybczynski effects of an additional professional.

\subsubsection{Extension: trade in intermediate inputs}

In the first extension, we add intermediate goods trade. Above, when endowment with all factors is increased, the introduction of trade in intermediates leads to smaller positive output effects in the own country, compared to the situation with only trade in final goods. This is no longer the case; instead, the impact of trade in intermediates on the Rybczynski effects can go in either direction.

\footnotetext{
${ }^{12}$ http://www.ilo.org/public/english/bureau/stat/isco/isco88/2.htm

${ }^{13}$ For more information on negative coefficients of this type, see Fisher and Marshall (2011). Their OLS estimation of factor rewards is identical to our calculation of aggregate Rybczynski effects. They find a positive reward for professional occupations in the United States, but a negative reward for education and healthcare occupations. The ISCO-88 class of "Professionals" includes science and engineering professionals, health professionals, teaching professionals, business and administration professionals, information and communications technology professionals, and legal, social, and cultural professionals.
} 


\begin{tabular}{l|ccccccccccc|c}
\hline & AT & CZ & DK & ES & FI & GE & IT & NL & SL & SW & UK & $\Sigma$ \\
\hline AT & 13,052 & $-1,058$ & 175 & -1 & -46 & $-1,118$ & 1,761 & 12 & 485 & -939 & 0 & -729 \\
CZ & -643 & $-10,582$ & -29 & -71 & -106 & -504 & -93 & -241 & -19 & 222 & -98 & $-1,582$ \\
DK & 64 & -98 & $-23,473$ & 10 & 55 & -162 & -223 & -32 & 20 & -741 & -11 & $-1,120$ \\
ES & 363 & -582 & 718 & 27,188 & -15 & -170 & 3,459 & 76 & 408 & -381 & 135 & 4,012 \\
FI & 27 & -62 & 534 & -10 & 32,858 & -308 & 483 & -32 & 11 & $-3,195$ & 94 & $-2,457$ \\
GE & 2,972 & -768 & 2,312 & 118 & -337 & 34,452 & $-2,350$ & -659 & -46 & 3,729 & 49 & 5,021 \\
IT & 3,276 & -308 & 1,915 & 918 & 489 & 915 & $-82,223$ & 416 & 3,305 & 774 & 603 & 12,303 \\
NL & -99 & $-1,238$ & 840 & -35 & -227 & $-1,304$ & 1,395 & 7,735 & 118 & $-1,867$ & 403 & $-2,015$ \\
SL & -17 & 372 & 46 & -4 & -12 & 197 & $-4,201$ & -128 & 4,332 & 10 & -119 & $-3,948$ \\
SW & 37 & -8 & 3,373 & 5 & -591 & -51 & -383 & -248 & -26 & $-78,055$ & -116 & 1,990 \\
UK & 361 & $-1,628$ & 341 & 121 & -393 & 136 & -346 & 245 & -266 & -971 & 21,067 & $-2,399$ \\
\hline$\Sigma$ & 6,341 & $-5,378$ & 10,134 & 1,051 & $-1,182$ & $-2,368$ & -499 & -591 & 3,989 & $-3,360$ & 940 & \\
\hline
\end{tabular}

Table 6. Economy-wide Rybczynski effects of an additional professional with intermediate input trade.

Another difference from the case above is that effects on other countries are now more often positive. Italy, Germany, Spain, and Sweden even have an aggregate positive effect on all other countries. Denmark is the country that gains most from an increase in the endowment with "Professionals" in all other countries, only losing from a higher endowment in the Czech Republic (and in Denmark itself). Other countries that gain from such a change are Austria, Slovenia, Spain, and the United Kingdom. The country that loses most is Sweden, mostly caused by a negative Rybczynski effect with "Professionals" in Finland. We conclude that a higher number of high-skilled workers often implies positive spillovers on output in other countries when capital is immobile.

\subsubsection{Additional extension: mobile capital}

Assuming capital to be perfectly mobile implies some important changes in the picture painted previously. The only country that benefits more from a higher endowment of high-skilled labor than in the case with immobile capital is Italy. More precisely, it is the only one that is harmed less: the Rybczynski effect is now $-65,102$ instead of $-82,223$ Euros as it was above. The Rybczynski effect of high-skilled workers in all other countries on their own output is smaller than found above. The effect is smaller at the expense of a generally higher effect on other countries' output when capital is mobile. In fact, summing over all other countries gives positive aggregate Rybczynski effects for high-skilled workers in all countries. The countries that cause the largest effect on all other countries are Denmark, Italy, the Czech Republic, and Germany. All of them have a very high impact on output in Sweden, which is the 


\begin{tabular}{l|ccccccccccc|c}
\hline & AT & CZ & DK & ES & FI & GE & IT & NL & SL & SW & UK & $\Sigma$ \\
\hline AT & 3,882 & 479 & 658 & 2 & -44 & $-1,287$ & 1,806 & 44 & 627 & 153 & 13 & 2,451 \\
CZ & -295 & $-14,481$ & 6,682 & -35 & -64 & -480 & -929 & -29 & 42 & 8,621 & -85 & 13,428 \\
DK & 267 & 9,399 & $-47,641$ & 44 & 96 & 7 & $-1,186$ & 63 & 29 & 6,930 & -75 & 15,574 \\
ES & 435 & 844 & 1,132 & 25,639 & -4 & -169 & 2,995 & 124 & 513 & 985 & 154 & 7,009 \\
FI & 81 & 1,224 & 1,122 & -14 & 31,273 & -486 & 966 & 77 & 49 & $-1,739$ & 223 & 1,504 \\
GE & 3,438 & 1,325 & 1,884 & 134 & -286 & 34,209 & $-3,644$ & -303 & 275 & 7,667 & 100 & 10,590 \\
IT & 3,367 & -1 & 1,506 & 917 & 507 & 978 & $-65,102$ & 458 & 3,735 & 2,109 & 577 & 14,154 \\
NL & 0 & 489 & 1,144 & -40 & -196 & $-1,471$ & 1,359 & 1,387 & 161 & -47 & 471 & 1,870 \\
SL & -286 & 1,145 & 358 & -65 & -10 & -457 & 3,272 & -22 & 930 & 20 & 104 & 4,059 \\
SW & 169 & 3,646 & 5,546 & 13 & -589 & -157 & -523 & -112 & 11 & $-137,953$ & 31 & 8,034 \\
UK & 397 & -702 & 440 & 106 & -364 & 70 & -414 & 311 & -216 & 1,045 & 19,462 & 673 \\
\hline$\Sigma$ & 7,572 & 17,848 & 20,472 & 1,061 & -954 & $-3,451$ & 3,701 & 612 & 5,228 & 25,744 & 1,513 & \\
\hline
\end{tabular}

Table 7. Economy-wide Rybczynski effects of an additional professional with intermediate input trade and mobile capital.

country that gains most from aggregate changes in all other countries. Moreover, only one country-Germany-is affected negatively by a higher endowment with high-skilled in all other countries. This is an interesting result since it suggests that capital flows out of the country where endowment with high-skilled workers is increased. This means that sectors that are relatively high-skilled-labor-intensive and, hence, expand as a result of the endowment shock, seem to be using relatively little capital. The sectors in which output is reduced must be relatively capital-intensive, allowing capital to flow out to other countries. Compared to the situation with immobile capital, the positive spillovers of high-skilled workers on output in other countries are even larger.

\section{Conclusion}

This paper makes a two-fold contribution to the literature. First, we theoretically derive a method to calculate a matrix of international bilateral Rybczynski effects using data from only the supply side of the economy. The international Rybczynski effect is the aggregate output change in one country given that endowment with one or more factors in another country increases. Second, based on this matrix, we describe the economic structure of 11 EU countries. We begin by assuming free trade in final goods and gradually introduce two channels of international interaction: trade in intermediate inputs and international mobility of capital.

We find that all countries increase their output when they obtain an additional unit of 
each type of labor. When introducing traded intermediate inputs, the bilateral effects on other countries are mostly negative and the aggregate effect that endowment changes in one country have on the sum of output changes in all other countries is always negative. When we additionally introduce internationally mobile capital, the pattern remains qualitatively the same. However, Rybczynski effects on output in the own country are generally larger and Rybczynski effects on output in other countries are generally larger in absolute terms, which implies flows of capital into the country where endowment of all other factors is raised.

Calculating Rybczynski effects for high-skilled "Professionals", we find that some countries lose in terms of output from such a change. This negative effect is caused by the fact that a higher endowment with one factor implies movements of other factors between sectors and a different production volume of intermediate inputs, which may also imply movements into sectors where factors or intermediate inputs are less productive. ${ }^{14}$ The international integration of the production process through intermediate inputs leads to a large number of positive spillover Rybczynski effects on other countries. For some countries, even the aggregate effect on the "rest of the world" is positive. Assuming capital to be perfectly mobile implies mostly smaller effects on output in the own country and larger effects on output in other countries. The aggregate effect on the sum of all other countries is now positive for all countries. This is caused by an outflow of capital as a response to a higher endowment with high-skilled "Professionals".

\section{References}

Agrawal, A., Kapur, D., Mchale, J. And A. Oettl (2011). "Brain Drain or Brain Bank? The Impact of Skilled Emigration on Poor-country Innovation", Journal of Urban Economics, 69, 43-55.

Albert, A. (1972). "Regression and the Moore-Penrose Pseudoinverse", New York: Academic Press.

Bjerhammar, A. (1951). "Application of Calculus of Matrices to Method of Least Squares; with Special References to Geodetic Calculations", Transactions of the Royal Institute of Technology, Stockholm, 49, $1-86$.

BMbF (German Federal Ministry of Education and Research) (2010) . "Ideen. Innovation. Wachstum. Hightech-Strategie 2020 für Deutschland. (Ideas. Innovation. Growth. Hightech-Strategy 2020 for Germany)", BMBF, Berlin.

Brezzi, M. And M. Piacentini (2010). "Labour Mobility and Development in Dynamics in OECD Regions", Paris: OECD Publishing.

\footnotetext{
${ }^{14}$ Having calculated an economy-wide rate of return for each factor, sectors with less productive factors are those where the implied cost of production exceeds the value of output.
} 
Caliendo, L. and F. Parro (2012). "Estimates of the Trade and Welfare Effects of NAFTA", NBER Working Paper No. 18508.

Campa, J. And L. S. Goldberg (1997). "The Evolving External Orientation of Manufacturing: A Profile of Four Countries", Federal Reserve Bank of New York Economic Policy Review, 3, 53-81.

Feenstra, R. C. And G. H. Hanson (1996). "Globalization, Outsourcing, and Wage Inequality", American Economic Review Papers and Proceedings, 86, 240-245.

Feenstra, R. C. And G. H. Hanson (1999). "The Impact of Outsourcing and High-technology Capital on Wages: Estimates for the United States, 1979-1990", Quarterly Journal of Economics, 114, 907-940.

Fisher, E. And K. Marshall (2011). "The Structure of the American Economy", Review of International Economics, 19, 15-31.

Fitzgerald, D. and J. C. Hallak (2004). "Specialization, Factor Accumulation, and Development", Journal of International Economics, 64, 277-302.

Florida, R. (2002). "The Rise of the Creative Class", New York: Basic Books.

Florida, R. (2005). "Cities and the Creative Class", New York and London: Routledge.

Hanson, G. H., R. J. Mataloni Jr., and M. J. Slaughter (2001). "Expansion Strategies of US Multinational Firms", in Rodrik, D. and S. M. Collins (eds.), Brookings Trade Forum 2001, Washington, DC: Brookings Institution Press, 245-294.

Hanson, G. H., R. J. Mataloni Jr., and M. J. Slaughter (2005). "Vertical Production Networks in Multinational Firms", Review of Economics and Statistics, 87, 664-678.

Harrigan, J. (1997). "Technology, Factor Supplies, and International Specialization: Estimating the Neoclassical Model", American Economic Review, 87, 475-494.

Hummels, D., J. Ishii, And K.-M. Yi (2001). "The Nature and Growth of Vertical Specialization in World Trade", Journal of International Economics, 54, 75-96.

Hummels, D., D. Rappoport, And K.-M. Yi (1998). "Vertical Specialization and the Changing Nature of World Trade", Federal Reserve Bank of New York Economic Policy Review, 4, 79-99.

Hunt, J. (2011). "Which Immigrants Are Most Innovative and Entrepreneurial? Distinctions by Entry Visa", Journal of Labor Economics, 29, 417-457.

Hunt, J. And M. Gauthier-Loiselle (2010). "How Much Does Immigration Boost Innovation?", American Economic Journal: Macroeconomics, 2, 31-56.

Johnson, R. And G. Noguera (2012). "Accounting for Intermediates: Production Sharing and Trade in Value Added", Journal of International Economics, Vol. 86(2), 224-236.

Kohli, U. (1991). "Technology, Duality, and Foreign Trade: The GNP Function Approach to Modeling Imports and Exports", Ann Arbor: University of Michigan Press.

Mahony, M. And M. Timmer (2009). "Output, Input and Productivity Measures at the Industry Level: The EU KLEMS Database", Economic Journal, 119, 374-403.

Marão, D. C., R. Fabling, and S. Stillman (2011). "Immigration and Innovation", IZA Discussion Papers, No. 5686, Institute for the Study of Labor (IZA).

Moore, E. H. (1920). "On the Reciprocal of the General Algebraic Matrix", Bulletin of the American Mathematical Society, 26, 394-395.

Niebuhr, A. (2010). "Migration and Innovation: Does Cultural Diversity Matter for Regional R\&D Activity?", Papers in Regional Science, 89, 563-585.

OECD (2002). "The OECD Input-Output Database", Paris: OECD Publishing.

OECD (2008). "The Global Competition for Talent: Mobility of the Highly Skilled", Paris: OECD Publishing.

OECD (2009). "The Global Competition for Talent", OECD Policy Brief, Paris: OECD Publishing.

OECD (2011). "Regions and Innovation Policy", OECD Reviews of Regional Innovation, OECD Innovation Strategy, Paris: OECD Publishing.

Opp, M., H. Sonnenschein, and C. Tombazos (2009). "Rybczynski's Theorem in the Heckscher-Ohlin World - Anything Goes", Journal of International Economics, 79(1), 137-142.

Ozgen, C., P. NiJkamp, and J. Poot (2011). "Immigration and Innovation in European Regions", IZA Discussion Papers, No. 5676, Institute for the Study of Labor (IZA). 
Penrose, R. (1955). "A Generalized Inverse for Matrices", Proceedings of the Cambridge Philosophical Society, 51, 406-413.

Reiner, C. (2010). "Brain Competition Policy as a New Paradigm of Regional Policy: A European Perspective", Papers in Regional Science, 89, 449-461.

Rybczynski, T. (1955). "Factor Endowments and Relative Commodity Prices", Economica, 22, 336-341.

Solimano, A. (2008). "Causes and Consequences of Talent Mobility", in Solimano, A. (ed.), The International Mobility of Talent: Types, Causes and Development Impact, Oxford: Oxford University Press, $1-18$.

Trefler, D. And S. C. Zhu (2010). "The Structure of Factor Content Predictions." Journal of International Economics, 82: 195-207.

Trippl, M. And G. Maier (2010). "Knowledge Spillover Agents and Regional Development", Papers in Regional Science, 89, 229-233.

YeAts, A. J. (2001). "Just How Big Is Global Production Sharing?", in Arndt, S. W. and H. Kierzkowski (eds.), Fragmentation: New Production Patterns in the World Economy, Oxford: Oxford University Press, 108-43.

Yı, K.-M. (2003). "Can Vertical Specialization Explain the Growth of World Trade?", Journal of Political Economy, 111, 52-102. 


\section{Ifo Working Papers}

No. 160 Potrafke, N., Minority Positions in the German Council of Economic Experts: A Political Economic Analysis, April 2013.

No. 159 Kauder, B. and N. Potrafke, Government Ideology and Tuition Fee Policy: Evidence from the German States, April 2013.

No. 158 Hener, T., S. Bauernschuster and H. Rainer, Does the Expansion of Public Child Care Increase Birth Rates? Evidence from a Low-Fertility Country, April 2013.

No. 157 Hainz, C. and M. Wiegand, How does Relationship Banking Influence Credit Financing? Evidence from the Financial Crisis, April 2013.

No. 156 Strobel, T., Embodied Technology Diffusion and Sectoral Productivity: Evidence for 12 OECD Countries, March 2013.

No. 155 Berg, T.O. and S.R. Henzel, Point and Density Forecasts for the Euro Area Using Many Predictors: Are Large BVARs Really Superior?, February 2013.

No. 154 Potrafke, N., Globalization and Labor Market Institutions: International Empirical Evidence, February 2013.

No. 153 Piopiunik, M., The Effects of Early Tracking on Student Performance: Evidence from a School Reform in Bavaria, January 2013.

No. 152 Battisti, M., Individual Wage Growth: The Role of Industry Experience, January 2013.

No. 151 Röpke, L., The Development of Renewable Energies and Supply Security: A Trade-Off Analysis, December 2012.

No. 150 Benz, S., Trading Tasks: A Dynamic Theory of Offshoring, December 2012.

No. 149 Sinn, H.-W. und T. Wollmershäuser, Target-Salden und die deutsche Kapitalbilanz im Zeichen der europäischen Zahlungsbilanzkrise, Dezember 2012. 
No. 148 Nagl, W., Better Safe than Sorry? The Effects of Income Risk, Unemployment Risk and the Interaction of these Risks on Wages, November 2012.

No. 147 Mang, C., Online Job Search and Matching Quality, November 2012.

No. 146 Link S., Single-Sex Schooling and Student Performance: Quasi-Experimental Evidence from South Korea, October 2012.

No. 145 Nagl, W., Wage Compensations Due to Risk Aversion and Skewness Affection - German Evidence, October 2012.

No. 144 Triebs, T.P. and S.C. Kumbhakar, Productivity with General Indices of Management and Technical Change, October 2012.

No. 143 Ketterer, J.C., The Impact of Wind Power Generation on the Electricity Price in Germany, October 2012.

No. 142 Triebs, T.P., D.S. Saal, P. Arocena and S.C. Kumbhakar, Estimating Economies of Scale and Scope with Flexible Technology, October 2012.

No. 141 Potrafke, N. und M. Reischmann, Fiscal Equalization Schemes and Fiscal Sustainability, September 2012.

No. 140 Fidrmuc, J. and C. Hainz, The Effect of Banking Regulation on Cross-Border Lending, September 2012.

No. 139 Sala, D. and E. Yalcin, Export Experience of Managers and the Internationalization of Firms, September 2012.

No. 138 Seiler, C., The Data Sets of the LMU-ifo Economics \& Business Data Center - A Guide for Researchers, September 2012.

No. 137 Crayen, D., C. Hainz and C. Ströh de Martínez, Remittances, Banking Status and the Usage of Insurance Schemes, September 2012.

No. 136 Crivelli, P. and J. Gröschl, The Impact of Sanitary and Phytosanitary Measures on Market Entry and Trade Flows, August 2012.

No. 135 Slavtchev, V. and S. Wiederhold, Technological Intensity of Government Demand and Innovation, August 2012. 